\title{
The Relationship Between the Level of Students Satisfaction Towards the Primary Service Strengthening Program with UKMPPD Graduation
}

\author{
${ }^{1}$ Amir, Suliati P., ${ }^{2}$ Mappaware, Nasrudin A., ${ }^{3}$ Irwan, Andi Alamanda, ${ }^{4}$ Latief, \\ Shofiyah, ${ }^{5}$ Mokhtar, Shulhana, ${ }^{6}$ Siddiq, Sri Ainun Zainal
}

suliatip.amir@umi.ac.id ${ }^{1}$,ernase@yahoo.com ${ }^{2}$, andialamanda.irwan@umi.ac.id ${ }^{3}$, shofivah.latief@umi.ac.id ${ }^{4}$, shulhana.mokhtar@umi.ac.id ${ }^{5}$, sriainun169@gmail.com ${ }^{6}$

\begin{abstract}
The process of quality assurance is a strategic matter implemented by educational institutions. Measuring the level of student satisfaction is one method of evaluating them. Therefore, we need to know how the students' reaction about the innovation of institution Primary Service Strengthening program and the relationship with the UKMPPD results. Methods: This research is a descriptive analytic study with a quantitative design with total sampling. The participants were the students in the clinical phase who take the medical professional program student competency test (UKMPPD) batch I (February 2020). All participants were then asked to fill out a questionnaire about satisfaction with the primary service strengthening program implemented in the institution. The programs are small group learning (SGL) in the first week of each stage, clinical skills training (CST), OSCE section in each department and expert lectures (based on SKDI). Then we analyzed based on the graduation of UKMPPD. Results: The number of samples in this study were 68 participants. The highest level of student satisfaction with the Primary Service Strengthening Program at UMI's Faculty of Medicine was obtained (100\%), namely tutorial in the Small Group Learning (SGL) program, Clinical Skill Training (CST), OSCE Section and Expert Lectures/seminar.

There is a relationship between the level of student satisfaction variable towards the Primary Service Strengthening Program and the UKMPPD Graduation Result in the batch I (February 2020 Period) at FK UMI with a significance value $<0.05$ and a positive direction. Conclusion: It is found that the relationship between the two variables has a high significance level, so we suggest that the program will continue with improvements.
\end{abstract}

Keywords: Student satisfaction, UKMPPD.

\section{INTRODUCTION}

In recent years, the graduation rate of UKMPPD of Medical Faculty, Universitas Muslim Indonesia (UMI) has increased significantly. In 2017, Medical Faculty UMI has obtained UKMPPD graduation by $76,47 \%$ of the national average value, $62,89 \%$.

The high passing rate cannot be separated from various supporting factors. Several factors that contributed to the outcome of UKMPPD were the learning activities at clinical phase like bedside teaching, management of emergency and non-emergency patients with medical and non-medical treatments, providing health services in the form of promotive, preventive, curative and rehabilitative activities, academic activities such as discussion of cases, scientific base discussion, reading journals, morning reports, and so on. In order to determine the level of student ability in each area, a computer-based exam is conducted [1].

Primary service programs that are considered capable of supporting students in graduating UKMPPD such as medical subject enrichment in the form of small group learning (SGL) for topics of higher level competencies and clinical skills training (CST) of general skills for doctors in the first week of department rotation, clinical rotation at Community Health Center services, and several exam programs provided by the faculty. This research was made to know the level of student satisfaction towards primary service strengthening program of the Faculty of Medicine Universitas Muslim Indonesia and how this is correlated with the graduation of UKMPPD Batch I for the period of February 2020.

Those programs are expected to help Universitas Muslim Indonesia and other universities to be able to increase the passing rate of their students in the next $U j i$ 


\section{Kompetensi Mahasiswa Program Profesi Dokter (UKMPPD).}

\section{LITERATURE REVIEW}

\subsection{Primary Service Strengthening Program}

The medical profession program or clinical education is a continuing education after undergraduate program to obtain a medical degree in four semesters. The profession program students are students of the Faculty of Medicine Universitas Muslim Indonesia that have registered and meet the requirements setting by university. The clinical training phase for the students is carried out in hospital, public health center, or related health agencies [2]

\subsubsection{Orientation and Pre-Comprehensive Test}

Orientation is considered as student activity before entering clinical clerkship. Pre-comprehensive test is an exam that is implemented using the Computer Based Test (CBT) method after the orientation is finished, right before the students start the clinical clerkship activities [3]. The programs in the clinical phase are programs that have been implemented by several medical faculties for students who have completed the academic stage which will then continue to the profession program or clinical stage [4].

\subsubsection{Pre-Test Section}

Before entering the clinical clerkship cycle, clinical students should take a pre-test in the department in which they will undergo the clinical clerkship [3]

\subsubsection{Small Group Learning (SGL)}

Small group is a group of people consisting of more than one member who form a group. The number of members in the group should not be too much, it is feared that the interaction between groups will not work effectively. Small group learning is relevant to adult learning and in clinical situations students can discuss, participate actively, provide feedback, and reflection [5,6].

Small Group Learning that is implemented is a step-bystep discussion. On the guidance of UKMPPD, activities carried out through discussion to discuss questions and theories. The role of supervisor in this small group will be as a leader, guide, facilitator, commentator, and counselor [7].

\subsubsection{Clinical Skill Training (CST).}

Clinical skills training is a training that aimed at preparing medical students to face clinical clerkship. Ideally, clinical skills training starts at the beginning of the semester since the training will increase student interest in learning and provide better preparation for undergoing clinical clerkship [8].

Clinical skill assessment generally evaluates the level of 'knows' and 'knows how'. Assessment at this level cannot confirm the competence of a doctor. Assessment of clinical skills to the level of 'shows how' and 'does' need to be done [9].

\subsubsection{Portfolio and referat}

Referat is an individual task where students make scientific papers on agreed themes and within the frame of general practitioner competence and prioritize cases belonging to $3 \mathrm{~A}, 3 \mathrm{~B}$, or $4 \mathrm{~A}$ categories. The aim of the referat is to train young doctors in critical thinking, scientific writing, and applying evidence-based medicine [10].

The portfolio used in education contains evidence of how the trainee fulfills the assignment and how his competence has developed. Portfolios may be digital, or paper based, and content may be defined or submitted at the discretion of students. Regardless of the variation in content and format, a portfolio is essentially reporting on work that has been done, feedback received, progress made, and plans for improving competency. In addition, portfolios can stimulate reflection since gathering evidence for inclusion in a portfolio requires looking back and analyzing what someone has accomplished [11].

\subsubsection{Department Examination.}

Department Examination (Case Examination and Post Test) is conducted after clinical students finish the clinical clerkship cycle in each department [3].

\subsubsection{Mid Comprehensive}

Mid Comprehensive is an exam that is carried out by students after completing the clinical clerkship program at level 1 (8 departments) and related tasks in the department (SKDI seminar and portfolio) before the graduation to level 2 [3].

\subsubsection{Comprehensive.}

Comprehensive is an exam that is carried out by students after completing the entire clinical clerkship cycle at level 1 and 2 (16 departments) or have completed more 
than $50 \%$ of the last department of the cycle and have completed the related tasks in the department (SKDI seminars and portfolio). All these tasks must be fulfilled before the graduation of student from Medical Profession Program [3].

\subsubsection{Scientific Day}

Scientific Day is special day where students that are currently running the clinical clerkship in Makassar area gathering every Saturday at the campus in order to attend case reflections in the ongoing department and SKDI seminar [3].

\subsubsection{SKDI Seminar}

Indonesian Doctor Competency Standards (SKDI) are qualifications of a doctor's ability which include the attitudes, knowledge and skills of graduates according to agreed national standards. In the SKDI seminar, the topic focuses on disease cases in accordance with SKDI where all the students are required to attend the seminar to broaden their horizons [12].

\subsubsection{Case reflection in each department}

Case reflection is presentation activity on the results of case analysis that have been taken and carried out at the primary services, describe complete with the interventions. The results of the case analysis presentation should be collected in the form of a case report [13].

\subsubsection{UKMPPD Preparation Class}

In order to strengthen student preparation for national competency test (Uji Kompetensi Mahasiswa Program Profesi Dokter or UKMPPD), Faculty of Medicine Universitas Muslim Indonesia provides mentoring activities in the form of Peer Mentors and Expert Lectures [3].

\subsubsection{Peer Mentor}

Peer mentoring is a mentoring method in which the teacher or tutor is a person whose age is not much different from the person that the he will teach. In the peer mentoring implemented by the faculty, the mentors are those who have just passed the UKMPPD and have received a national registration letter (surat tanda registrasi or STR). Meanwhile, those who participate in the mentoring class are those who are just about to take the UKMPPD $[3,14]$.

\subsubsection{Expert Lecture}

An expert lecture is a lecture conducted by someone who is widely considered to be a trusted source of certain knowledge and expertise whose talent is to judge and decide something correctly, according to the rules and status by the others or in certain special fields. In the medical profession program, the expert is a specialist doctor [15].

\subsection{Factors affecting the exam result}

Factors that can affect differences in learning or exam results for each student consist of internal factors and external factors. Internal factors, namely factors that come from within the individual such as health, intelligence and talent, interest and motivation, and way of study. External factors, namely factors that come from outside the individual such as family, society, surrounding environment [16].

Other factors that can affect the result of the competency test are Grade Point Average (GPA) and length of the study [17].

\subsection{Medical student competency test (UKMPPD)}

Medical student competency test (UKMPPD) is a national final exam that every prospective doctor must pass with the aim of maintaining the quality of medical education graduates. This competency test is also a requirement for a doctor to obtain a national registration letter or Surat Tanda Registrasi (STR) [18].

\section{METHODS}

\subsection{Types of Research}

This research is a descriptive analytic study with a quantitative design with the total sampling method, aim to determine the relationship between the level of satisfaction of medical students to the primary care strengthening program with the UKMPPD Batch I graduation for the February 2020 period at the Faculty of Medicine, Universitas Muslim Indonesia.

\subsection{Location and Time of Research}

The research was conducted online using a google form questionnaire and carried out at each respondent's place. The research was conducted in March - June 2020.

\subsection{Sampling Methods}

The samples of this study were all the students of medical profession program at Faculty of Medicine, Universitas 
Muslim Indonesia who took part in the UKMPPD Batch I for the February 2020 period and met the inclusion criteria.

In this study, the Total Quota Sampling technique was used. This method is a form of non-probability sampling research, namely by choosing a name from the entire list of Professional Doctor Program Students who take UKMPPD Batch I for the February 2020 period who will then be asked to fill in the research questionnaire, students who do not fill in the given timeframe are declared unwilling be respondents in this study.

\subsection{Research Instruments}

Data instruments used in this study were the UKMPPD Batch I graduation data for the February 2020 period and data on the types of Primary Service Strengthening programs obtained from the Medical Professional Study Program, Faculty of Medicine, Universitas Muslim Indonesia as well as a questionnaire containing the Relationship between the Level of Satisfaction of Students in the Primary Service Strengthening Program with the UKMPPD Batch I Graduation for the February 2020 Period, which was shared online via google form.

\subsection{Objective Criteria}

a. Level of Student Satisfaction of the Doctor Profession Program.

Questionnaire Assessment:

$1=$ Totally Disagree (TD)

$2=$ Disagree $(\mathrm{D})$

$3=$ Enough $(\mathrm{E})$

$4=\operatorname{Agree}(\mathrm{A})$

$5=$ Totally Agree (TA)

Assessment of Result of the questionnaire

Not satisfied $=\mathrm{TD}+\mathrm{D}$

Satisfied $=\mathrm{E}+\mathrm{A}+\mathrm{TA}$

b. Medical student competency test (UKMPPD)

- Pass

- Not Pass

\section{RESULTS AND DISCUSSION.}

\subsection{Research Results}

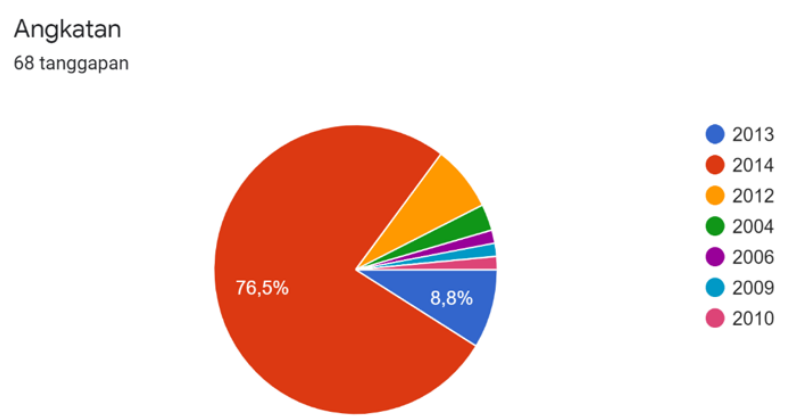

Fig. 1 Diagram of students' batch year

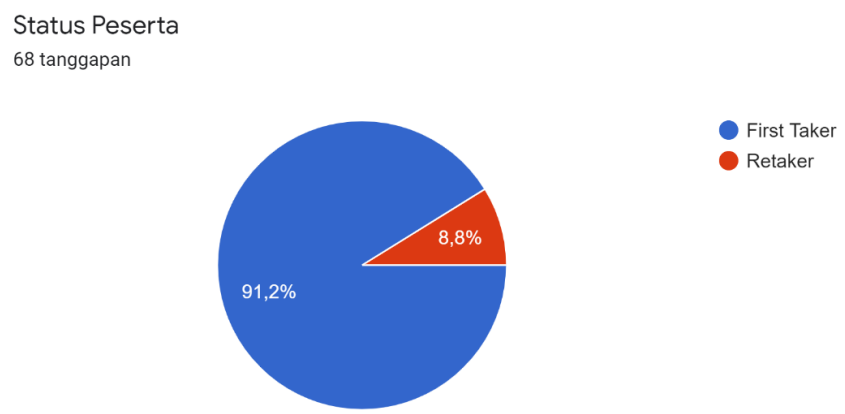

Fig. 2 Diagram of students' exam status

Table 1. Description of the characteristics of UKMPPD Participant Respondents Batch I for the Period of February 2020

\begin{tabular}{|c|c|c|c|c|c|}
\hline \multicolumn{3}{|c|}{ Batch Year } & \multicolumn{3}{|c|}{ Participant Status } \\
\hline Year & n & $\%$ & Type & n & $\%$ \\
\hline 2004 & 2 & $3 \%$ & & & \\
\hline 2006 & 1 & $1 \%$ & & & \\
\hline 2009 & 1 & $1 \%$ & First Taker & 62 & $91 \%$ \\
\hline 2010 & 1 & $1 \%$ & & & \\
\hline 2012 & 5 & $7 \%$ & Retaker & 6 & $9 \%$ \\
\hline 2013 & 6 & $9 \%$ & & & \\
\hline 2014 & 52 & $76 \%$ & & & \\
\hline Total & 68 & $100 \%$ & Total & 68 & $100 \%$ \\
\hline
\end{tabular}


Figure 3. Satisfaction Level of Medical Profession Students Towards Strengthening Program of FK UMI Primary Services.

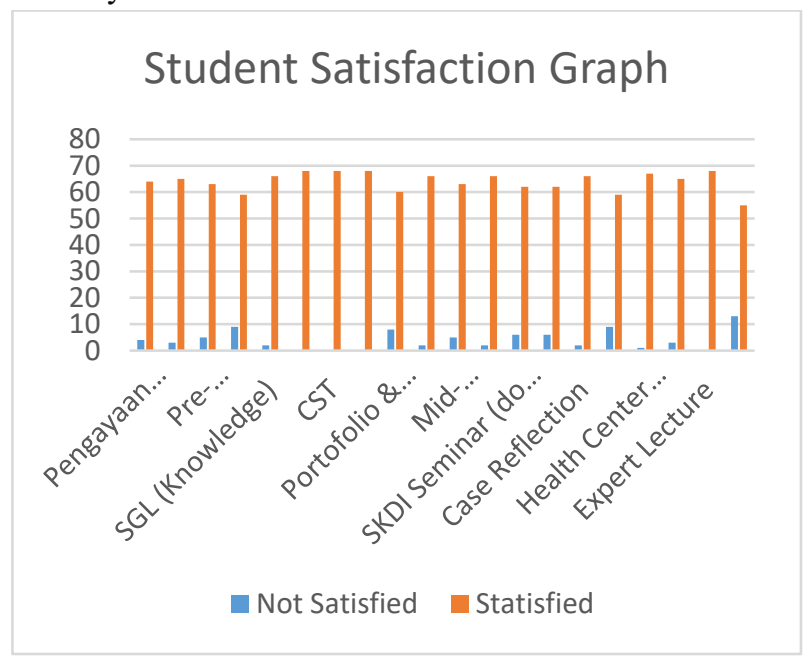

Based on Figure 3, it is found that all students are satisfied with the provision of tutors in the Small Group Learning (SGL) program, Clinical Skill Training (CST), OSCE Section and Expert Lecture.

Table 2. Results of the Correlation of the Student Satisfaction Level of the Primary Service Strengthening Program using the Pearson method.

\begin{tabular}{|c|c|c|c|c|c|c|}
\hline \multicolumn{7}{|c|}{ Correlation } \\
\hline & & $\begin{array}{c}\text { Totally } \\
\text { Disagre } \\
\text { e (1) }\end{array}$ & $\begin{array}{l}\text { Disa } \\
\text { gree } \\
(2)\end{array}$ & $\begin{array}{l}\text { Eno } \\
\text { ugh } \\
\text { (3) }\end{array}$ & $\begin{array}{l}\text { Agr } \\
\text { ee } \\
(4)\end{array}$ & $\begin{array}{c}\text { Totall } \\
y \\
\text { Agree } \\
(5)\end{array}$ \\
\hline \multirow{3}{*}{$\begin{array}{l}\text { Totall } \\
y \\
\text { Disag } \\
\text { ree } \\
\text { (1) }\end{array}$} & $\begin{array}{l}\text { Pearson } \\
\text { Correlation }\end{array}$ & 1 & .922 & .994 & .900 & $.891^{\prime \prime}$ \\
\hline & Sig. (2-tailed) & & .000 & .000 & .000 & .000 \\
\hline & $\mathrm{N}$ & 22 & 21 & 22 & 21 & 21 \\
\hline \multirow{3}{*}{$\begin{array}{l}\text { Disag } \\
\text { ree } \\
\text { (2) }\end{array}$} & $\begin{array}{l}\text { Pearson } \\
\text { Correlation }\end{array}$ & $.922^{\prime \prime}$ & 1 & .983 & .973 & $.961^{\prime \prime}$ \\
\hline & Sig. (2-tailed) & .000 & & .000 & .000 & .000 \\
\hline & $\mathrm{N}$ & 21 & 21 & 21 & 21 & 21 \\
\hline \multirow[t]{3}{*}{$\begin{array}{l}\text { Enou } \\
\text { gh (3) }\end{array}$} & $\begin{array}{l}\text { Pearson } \\
\text { Correlation }\end{array}$ & $.994^{\prime \prime}$ & $.883^{\prime}$ & 1 & .895 & $.887^{\prime \prime}$ \\
\hline & Sig. (2-tailed) & .000 & .000 & & .000 & .000 \\
\hline & $\mathrm{N}$ & 22 & 21 & 22 & 21 & 21 \\
\hline \multirow[t]{3}{*}{$\begin{array}{l}\text { Agree } \\
\text { (4) }\end{array}$} & $\begin{array}{l}\text { Pearson } \\
\text { Correlation }\end{array}$ & $.900^{\prime \prime}$ & $.973^{\circ}$ & .895 & 1 & $.995^{\prime \prime}$ \\
\hline & Sig. (2-tailed) & .000 & .000 & .000 & & .000 \\
\hline & $\mathrm{N}$ & 21 & 21 & 21 & 21 & 21 \\
\hline \multirow{3}{*}{$\begin{array}{l}\text { Totall } \\
\text { y } \\
\text { Disag } \\
\text { ree } \\
\text { (5) }\end{array}$} & $\begin{array}{l}\text { Pearson } \\
\text { Correlation }\end{array}$ & $.891^{\prime \prime}$ & $.961^{\circ}$ & .987 & .995 & 1 \\
\hline & Sig. (2-tailed) & .000 & .000 & .000 & .000 & \\
\hline & $\mathrm{N}$ & 21 & 21 & 21 & 21 & 21 \\
\hline
\end{tabular}

By using the Pearson method, the results are:

1. Based on the Significance Value of Sig. (2tailed): From the output table above, it is known that the Sig. (2-tailed) has a value of 0.000 which is $<0.05$, which means that there is a significant correlation.

2. Based on the calculated $r$ value (Pearson correlation): it is known that $\mathrm{N}=68$ with a value of $r$ table $=0.235$, the $r$ count (Pearson correlation) for the "dissatisfied" category is $r$ $=0.926 * *$ and for the "satisfied" category $\mathrm{r}=$ $0.994 * *$ so that $\mathrm{r}$ count (Pearson correlation) $>r$ table, it can be concluded that there is a relationship or correlation between variables.

3. Based on the asterisk (*) SPSS: from the output above it is known that the Pearson correlation value between each connected variable has two asterisks $(* *)$, which means that there is a correlation between the variables associated with a significance level of $1 \%$.

\section{DISCUSSION}

The results showed that there was a significant relationship between the level of student satisfaction with UKMPPD graduation with a significance value $<0.05$ and the Pearson correlation value for the satisfaction level of "dissatisfied" $\mathrm{r}=0.926^{* *}$ and the level of satisfaction with the "satisfied" category of 0.994 . $^{* *}$ The value of $r$ or the Pearson correlation which is close to number 1 and the presence of two asterisks $(* *)$ indicates that the relationship between the two variables is getting stronger or almost perfect.

Research by Mashirosyan et al in Armenia reported that satisfaction with education services affects academic achievement (Cumulative Achievement Index). Satisfaction will improve academic performance and outcomes [29].

This is different from the research conducted by Melani et al at the Faculty of Medicine, Padjajaran University, which found that there was no significant correlation between PPDS student satisfaction and UKMPPD scores. This could be due to the smaller and homogeneous number of samples [19]. 


\section{CONCLUSION}

In addition to the factor of the level of student satisfaction with the primary service strengthening program, according to Ramdhoni, Pusparini et al, there are other factors that can affect exam results such as internal and external factors of students as well as other factors such as GPA and length of study [24-27] that have not been studied in this research.

\section{ACKNOWLEDGMENTS}

Alhamdulillah, first of all we would like to thank Allah SWT as we have managed to complete the study and been given the opportunity to take part in ICME. Secondly, we also express our gratitude for the support from Dean of Medical Faculty, Universitas Muslim Indonesia, Prof. dr. Syarifuddin Wahid, PhD, SpPA(K), DFM who initiated and fully supported all the programs at this professional phase. May Allah SWT always give His blessings.

\section{REFERENCES}

[1] Irma Suswaty, Rahayu. 2017. Validitas Prediktif Uji Kompetensi Mahasiswa Program Profesi Dokter (UKMPPD) Pada Tahap Profesi. Fakultas Kedokteran Universitas Muhammadiyah Malang. accessed through: http://ejournal.umm.ac.id/index.php/sainmed/articl e/viewFile/5553/528

[2] Log Book Komunikasi. 2019. Dosen Penasehat Akademik (PA) dengan Mahasiswa Program Profesi Dokter. Fakultas Kedokteran Universitas Muslim Indonesia. Rumah Sakit Ibnu Sina Yayasan Wakaf Universitas Muslim Indonesia.

[3] Bagian Profesi Fakultas Kedokteran UMI. 2015. Panduan Akademik Profesi Dokter. Fakultas Kedokteran Universitas Muslim Indonesia. Makassar.

[4] Kusnadi Yandi Agus. 2017. Program Pendidikan Profesi Dokter. accessed through: docplayer.info/31432355-Program-pendidikanprofesi-dokter.html

[5] Rika, Dwita, dkk. 2017. Metode Small Group Learning Dalam Persiapan Ukmppd Nasional Fakultas Kedokteran Universitas Lampung. Fakultas Kedokteran Universitas Lampung.

[6] Judy M Kim, Carol Jollie. 2007. Facilitating learning: Teaching and Learning methode. London. accessed through: https://faculty.londondeanery.ac.uk/elearning/small-group-
teaching/Facilitating_learning_teaching_learning_methods.pdf

[7] Edmunds, S., \& Brown, G. (2010).Effective small group learning: AMEE Guide No. 48. Medical Teacher. accessed through: https://www.ncbi.nlm.nih.gov/pubmed/20795801

[8] Ahmed AM. 2008. Discussion and Debate Role of clinical skills centers in maintaining and promoting clinical teaching. accessed through: http://citeseerx.ist.psu.edu/viewdoc/summary?doi= 10.1.1.473.4634 (8)

[9] Dwi R. 2010. Studi Kualitatif Pengetahuan dan Sikap Mahasiswa Klinik FK Unhas Terhadap Sistem Kepaniteraan Klinik Terkait Standar Kompetensi Dokter. Fakultas Kedokteran Universitas Hasanuddin Makassar.

[10] Kepaniteraan FK UMJ website. Pendidikan Tahap Profesi Refarat (Kognitif). Fakultas Kedokteran Universitas Muhammadiyah Jakarta. accessed through: http://kepaniteraan.fkkumj.ac.id/referatkognitif/

[11] Erik, Jan Van, dkk. 2007. Portfolios in medical education: why do they meetwith mixed success? A systematic review. Black well publishing. accessed through:

https://pendidikankedokteran.net/index.php/sample -levels/level-21/61-pengantar-mingguan/986portofolio-untuk-menilai-peningkatan-kompetensidokter

[12] Wayan Andita May Utama. 2015. Hakikat Seminar Pendidikan. Ganesha University of Education. Yogyakarta. accessed through: https://www.researchgate.net/publication/3150543 43_Hakikat_Seminar

[13] Departemen Pendidikan Profesi. Proses Kepaniteraan Klinik. Universitas Muhammadiyah Yogyakarta. accessed through: http://blog.umy.ac.id/abdulmuin/proseskepaniteraan-klinik/

[14] The Mentoring Partnership of Southwestern PA. 1901. Peer Mentor Handbook. Centre Avenue, Suite 103 Pittsburgh. accessed through: www.mentoringpittsburgh.org

[15] Poltekkes Kemenkes. 2017. Kuliah Pakar. Kesehatan Kementrian Kesehatan Semarang. accessed through: http://kebidanan.poltekkessmg.ac.id/?p=1627

[16] Dalyono, M. 2005. Psikologi Pendidikan. Jakarta. Rineka Cipta.

[17] Utomo B, Roostantia, Safitri. 2014. Faktor yang Berhubungan Terhadap Tingkat Kelulusan UKDI 
Dokter Baru Lulusan Fakultas Kedokteran Universitas Airlangga. Jurnal Pendidikan Kedokteran Indonesia. 3(1) : 18-27

[18] RISTEKDIKTI. 2015. Panduan Uji Kompetensi Mahasiswa Program Profesi Dokter (UKMPPD). Hal 2-10.

[19] Nur Melani Sari dkk. 2016. Korelasi Tingkat Kepuasan Mahasiswa Program Studi Profesi Dokter (PSPD) Dan Nilai Ujian Kompetensi Mahasiswa Program Profesi Dokter (UKMPPD). Fakultas Kedokteran Universitas Padjajaran. JK. Unila 1(2):296-301 